\title{
Adverse effects of foot-and-mouth disease vaccine in dairy cattle ${ }^{1}$
}

\author{
Jasmyne A. Robattini' ${ }^{2}$ Rogan M. Kumer², Gabriella S. Velho², Mônica M. Buttelli², \\ Átila C. Soares ${ }^{3}$, Luis Gustavo Corbellini ${ }^{4}$ and André G.C. Dalto ${ }^{2 *}$ (iD)
}

\begin{abstract}
Robattini J.A., Kumer R.M. Velho G.S., Buttelli M.M. Soares A.C., Corbellini L.G. \& Dalto A.G.C. 2020. Adverse effects of foot-and-mouth disease vaccine in dairy cattle. Pesquisa Veterinária Brasileira 40(8):589-592. Setor de Grandes Ruminantes, Faculdade de Veterinária, Universidade Federal do Rio Grande do Sul, Av. Bento Gonçalves 9090, Porto Alegre, RS 91540-000, Brazil. *Corresponding author: andre.dalto@ufrgs.br

Foot-and-mouth disease represents an important barrier to the international commerce of animal products, potentially associated with significant economic losses. The systematic vaccination of bovines and buffaloes was fundamental for the eradication of this disease; however, the use of vaccines can lead to reactions at the application site. The objectives of this study were to evaluate the effects of the vaccination protocol to the production of dairy cows and to observe the occurrence of vaccinal reactions in the animals. At one property located in the municipality of Salvador do Sul, Rio Grande do Sul, 270 dairy cows were vaccinated against foot-and-mouth disease in May 2019. The vaccine was administered via a subcutaneous application using disposable syringes and needles for each animal. Inspection of the animals was performed before and 20 days after the vaccination to verify the presence of reactions to the vaccine. The study's sample was set by convenience, including 203 lactating animals with or without bovine somatotropin (BST) administration during the data collection period, which was limited to 20 days before and 20 days after the vaccination. Milk production data was obtained through SmartDairy ${ }^{\circledR}$ HerdMetrix $^{\mathrm{TM}}$ software, tabulated in electronic spreadsheets using Microsoft Excel ${ }^{\circledR}$ and processed using the program SAS ${ }^{\circledR}$, considering a $5 \%$ significance level for mixed model statistical analysis. A total of 160 animals $(78.82 \%)$ presented local lesions at the application site, even when the recommended vaccination practices were followed, suggesting that the high reaction power was provoked by the vaccinal components. In regards to milk production, a statistically significant $(\mathrm{p}<0.05)$ decrease of $0.30 \mathrm{~kg}$ of milk per animal/day was observed in the average daily production in the 20 days post-vaccination. These results demonstrate the local and systemic effects caused by the foot-and-mouth disease vaccine, evidenced by reduced levels of milk production and the occurrence of vaccine reactions, implying significant economic losses.
\end{abstract}

INDEX TERMS: Adverse effects, foot-and-mouth disease, vaccine, dairy cattle, Aphthovirus, cattle diseases, eradication, vaccine reaction, milk production.

\begin{abstract}
RESUMO.- [Efeitos adversos da vacina contra febre aftosa em bovinos de leite.] A febre aftosa representa uma importante barreira no comércio internacional de produtos de origem animal, podendo acarretar em significativas perdas econômicas. A vacinação sistemática de bovinos e bubalinos foi fundamental para a erradicação da doença. No
\end{abstract}

\footnotetext{
${ }^{1}$ Received on April 13, 2020.

Accepted for publication on April 29, 2020.

${ }^{2}$ Setor de Grandes Ruminantes, Faculdade de Veterinária (Favet), Universidade Federal do Rio Grande do Sul (UFRGS), Av. Bento Gonçalves 9090, Porto Alegre, RS 91540-000, Brazil. E-mail: andre.dalto@ufrgs.br
}

entanto, a utilização de vacinas pode causar reações no local da aplicação. 0 objetivo deste trabalho foi avaliar os efeitos da vacina em bovinos leiteiros e observar a incidência de reações vacinais no local de aplicação. 0 estudo foi realizado numa propriedade leiteira do município de Salvador do Sul, Rio Grande do Sul, onde foram vacinados 270 bovinos

\footnotetext{
${ }^{3}$ Veterinarian, Salvador do Sul, RS 95750-000, Brazil.

${ }^{4}$ Laboratório Epidemiologia Veterinária (Favet), Faculdade de Veterinária, Universidade Federal do Rio Grande do Sul (UFRGS), Av. Bento Gonçalves 9090, Porto Alegre, RS 91540-000, Brazil.
} 
contra febre aftosa no mês de maio de 2019. A vacina foi administrada por via subcutânea, com seringas e agulhas descartáveis para cada animal. Foi realizada inspeção dos animais antes da vacinação e 21 dias após a vacinação, para verificar a presença de reações vacinais. A amostra foi definida por conveniência, incluindo 203 vacas em lactação com ou sem administração de somatotropina bovina (BST) durante o período de coleta de dados, que 1 foi de 20 dias antes e 20 dias após a vacinação. Estes dados de produção de leite foram obtidos através do software SmartDairy ${ }^{\circledR}$ HerdMetrix $^{\mathrm{TM}}$, tabulados em planilhas eletrônicas do Microsoft Excel ${ }^{\circledR} \mathrm{e}$

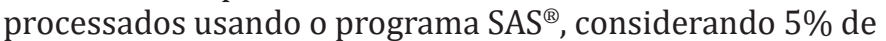
nível de significância para uma análise estatística modelo misto. Foi observado que 160 (78,82\%) vacas apresentaram lesões no local de aplicação, mesmo quando a aplicação era realizada de acordo com as boas práticas de vacinação, o que indica o alto poder de reação provocada pelos componentes da vacina. Em relação à produção de leite, observou-se uma redução significativa $(\mathrm{p}<0,05)$ na produção média diária de 0,30kg de leite por animal/dia nos 21 dias após a vacinação. Esses resultados demonstram os efeitos locais e sistêmicos provocados pela vacina da febre aftosa, evidenciados pela redução na produção de leite e pela incidência de reações vacinais, o que implica em significativas perdas econômicas.

TERMOS DE INDEXAÇÃO: Efeitos adversos, vacina, febre aftosa, bovinos de leite, Aphtovirus, doenças de bovinos, erradicação, reação vacinal, produção de leite.

\section{INTRODUCTION}

Foot-and-mouth disease (FMD) is a viral disease caused by the Aphthovirus, which affects all cloven-footed animals (Constable et al. 2017). It is a highly contagious disease that requires compulsory notification and represents an essential barrier to the international commerce of animal products, possibly leading to significant economic losses (IFAH 2012).

Currently, FMD is considered eradicated in Brazil and is recognized by the OIE as a "FMD-free zone" with vaccination since 2018 (MAPA 2018a). The systematic immunization of cattle and buffalo against FMD was fundamental in its eradication and for the change to its sanitary status in Brazil. Vaccination strategies are described in the Brazilian National Program for the Eradication of Foot-and-Mouth Disease (PNEFA), and the vaccination calendar varies by state and by region, being mandatory in both bovine and buffalo of all ages in all of the national territory, with the exception of the state of Santa Catarina, which has been recognized as an FMD-free zone without vaccination since 2007 (MAPA 2007). However, FMD vaccine use can cause reactions such as abscesses at the application site, which can be related to incorrect administration and contamination at the time of vaccination (De Souza et al. 2009). Additionally, the occurrence of exacerbated reactions to the vaccine has also been related to its adjuvant, a substance called saponin (CNA 2017). In an attempt to reduce these reactions, in 2018, the dose for the FMD vaccine was lowered from $5 \mathrm{ml}$ to $2 \mathrm{ml}$ and saponin was removed from its composition (MAPA 2018b).

Previous studies have shown that these reactions can cause important economic losses due to the lowering of carcass income in beef cattle (Moro et al. 2001, França Filho et al. 2006, Leal et al. 2014). Meanwhile, in dairy cattle, no articles with proven methodology have shown the influence of FMD vaccination on milk production.

The objectives of this article were to evaluate the effects of the FMD vaccination on the milk production of high-production dairy cattle and to assess the incidence of vaccine-caused reactions at the administration site.

\section{MATERIALS AND METHODS}

A total of 270 lactating cows with an average production of $25 \mathrm{~kg}$ of milk/cow/day were kept in a dairy farm located in the municipality of Salvador do Sul $\left(29^{\circ} 26^{\prime} 16^{\prime \prime}\right.$ S, 51 $30^{\prime} 39^{\prime \prime}$ W). The cows were confined in a Free Stall system and milked twice daily. According to the vaccination calendar against FMD developed by the "Ministério da Agricultura Pecuária e Abastecimento", all of the cows on the farm were vaccinated in May. Vaccines were acquired and stored at $2-8^{\circ} \mathrm{C}$ until administration and were applied subcutaneously at the post-scapular region using individual disposable $3 \mathrm{ml}$ syringes and hypodermic disposable $40 \times 1.2 \mathrm{~mm}$ needles for each animal.

Prior to vaccination, each animal was inspected in order to certify that there were no previous lesions present. A second inspection was conducted 20 days post-vaccination to detect the presence, dimensions, and amount of vaccinal reactions if any.

Bovine somatotropin (BST) was administered to the cows at 11-dayintervals starting at the 100th lactation day; thus cows that did not receive BST doses homogeneously during the observational period were excluded from the study. The study sample was therefore set by convenience, composed of 203 lactating animals with or without the administration of bovine somatotropin (BST) during the data collection period, a sample comprised of $139(68.47 \%)$ Holstein cows and 64 (31.53\%) Jersey cows.

For the sake of standardization, cows were sorted according to the lactation period, into either early phase ( $<100$ lactating days), medium phase (100 to 200 lactating days), or late phase ( $>200$ lactating days). For each cow, the momentum of vaccination was classified as " $\mathrm{B}$ ", i.e., 20 days before, and "A", 20 days after vaccination. Individual milk production of the 203 cows was obtained from 20 days before FMD vaccination until 20 days after vaccination, through use of the SmartDairy ${ }^{\circledR}$ HerdMetrix $^{\mathrm{TM}}$ software, which stores data from the Boumatic ${ }^{\circledR}$ milking machine. Data were tabulated in electronic Microsoft Excel ${ }^{\circledR}$ spreadsheets for better visualization of the herd's productive patterns and processed using the program SAS Studio ${ }^{\circledR}$ considering a $5 \%$ significance level for mixed model statistical analysis. The mixed model was fit to assess the effect of vaccination ('before' and 'after' vaccination; fixed effect) on the milk production (dependent variable) adjusted for lactation period ('early', medium', and 'late' phase) and BST usage. The model accounted for the repeated measure for each subject, using data from 203 cows with 40 observation each ( $\mathrm{n}=8,120$ observations). The procedure "PROC MIXED" with an 'unstructured' covariance was used. Interactions between vaccine and BST and vaccine and lactation phase were tested. The estimated marginal mean of milk production was extracted from the model using the "lsmeans" command of the SAS Studio. To analyze racial influence, the chisquare test was performed.

The current research was approved by the "Comissão de Ética no Uso de Animais" of "Universidade Federal do Rio Grande do Sul", Protocol number 23078.017735/2017-21 in a meeting held on October 25th, 2017 in Porto Alegre, Rio Grande do Sul, Brazil. 


\section{RESULTS}

Of the 203 cows in this study, none had previous lesions at the vaccination site administration. At 20 days post-vaccination, 160 cows $(78.82 \%)$ presented a local vaccinal reaction. Concerning breed characteristics, $83 \%$ of Holstein cows and $77 \%$ of Jersey cows presented reactions to the vaccine in the form of rounded, firm lesions, ranging from $10 \mathrm{~cm}$ to $25 \mathrm{~cm}$ (Fig.1).

The estimated marginal milk production before and after vaccination, adjusted for covariates (i.e., lactation period and BST) was $19.16 \mathrm{~kg}(\mathrm{SE}=0.95)$ and $18.86 \mathrm{~kg}(\mathrm{SE}=0.30)$, respectively. That means an estimated mean difference of $0.30 \mathrm{~kg}$ of milk per animal/day to the average daily production 20 days post vaccination. This difference in milk production was statistically significant $(\mathrm{p}=0.035)$. Interactions between the factors vaccine/BST and vaccine/lactation phase were not significant.

\section{DISCUSSION}

Even with the altered vaccine composition, which aimed to reduce vaccinal reactions (MAPA 2018b), as well as the methodology which followed good practices and vaccination protocols, a meaningful number of vaccinal reactions (78.82\%) was still found. This result differs from Moro et al. (2001), who observed only a $29.9 \%$ incidence of vaccinal reactions

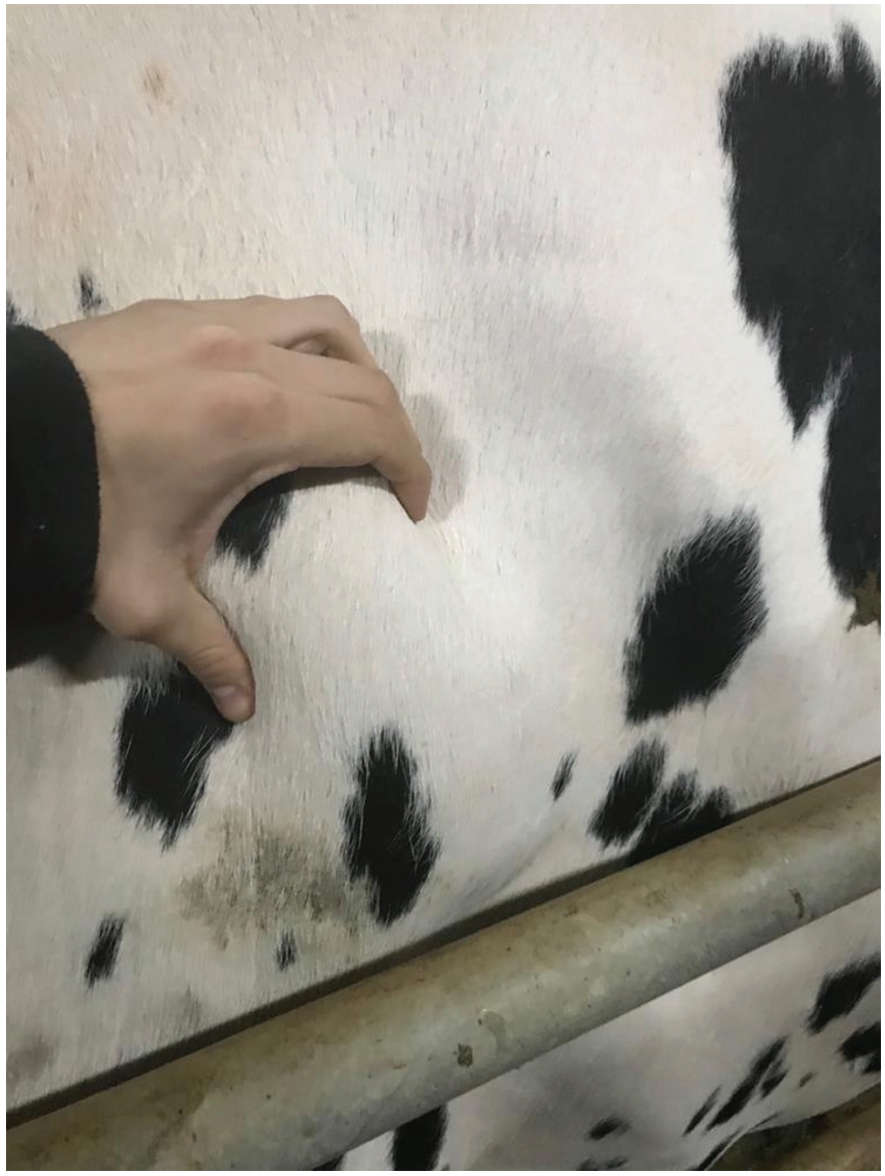

Fig.1. Rounded, firm vaccine reaction of approximately $25 \mathrm{~cm}$ in Holstein cattle 21 days after immunization against foot-andmouth disease. in culled bovine carcasses, and from Leal et al. (2014), who found reactions to the foot-and-mouth vaccine in 1,815 out of 5,000 culled bovines in a slaughterhouse $(36.3 \%)$. On the other hand, an important consideration is that these studies evaluated vaccinal reactions at culling, which could have resulted in a wider time gap between vaccination and lesion evaluation, potentially leading to a misevaluation due to lesion regression. Nevertheless, the present study demonstrates that in cases of vaccine administration followed by immediate evaluation, the majority of immunized animals presented a vaccinal reaction. George et al. (1995) proved that by administering the same vaccine against clostridiosis at several different dosages, the lowest dose $(2 \mathrm{ml})$ resulted in less vaccinal reactions compared to the highest dose $(5 \mathrm{ml})$, yet similar results were not achieved in the present study since most of the herd showed reactions even with the dose reduction. Another important factor that must be considered is the route of application of the vaccine, as our study was carried out subcutaneously and according to Lima et al. (2014) it was found that the animals submitted to the application of the vaccine by the subcutaneous route showed a greater post-vaccine reaction than the animals subjected to the intramuscular route.

The use of different disposable needles for each animal seeks to rule out contamination as a cause for vaccinal reactions (De Souza et al. 2009). Even though the reason for the occurrence of reactions cannot be determined, it is likely related to the composition of the vaccine itself: saponin was removed from the composition, but the oily adjuvant was sustained, which, according to Tizard (2002) can lead to granuloma formations at the administration site through a chronic inflammatory response. These granulomas can be either sterile or should there be contamination at administration, infected abscesses.

Both Jersey and Holstein cows presented a large number of vaccinal reactions; therefore no significant statistical difference between breeds was found in regards to vaccinal reaction prevalence, suggesting that the occurrence of these lesions does not follow any breed predisposition. Aside from the exacerbated local effects, systemic effects from the vaccination were also observed, highlighted by the significant decrease of milk production. This result should not be expected in an inactivated vaccine production such as the FMD, since these usually exhibit reactions restricted to the administration site. The possibility of systemic reactions related to the pyrogenic effect of the antigen and adjuvants has been previously mentioned in the literature, especially in oily emulsions and saponins (Martinod 1995).

In agreement with the dairy production results, Yeruham et al. (2001) observed that animals that presented vaccinal reactions to the FMD vaccine showed reduced levels of milk production in comparison with animals not presenting any vaccinal reaction eight days after vaccination. Conversely, Santos et al. (2019) found no influence of the FMD vaccination on milk production in the nine days following vaccination. Therefore, due to the scarcity of literature on the subject and the divergence of results, the current study included a wider observational period and the consideration of the influence of other factors, such as the use of BST, breed and lactation phase.

Interactions of the vaccine/BST and vaccine/lactation phase were not significant, showing that the average milk reduction seen after vaccination was similar regardless 
of hormonal administration or lactation phase. Such an observation is imperative in order to validate the findings disregarding external variables, such as the lactation phase and BST administration, since these are factors that could impact the average milk production or interfere in the analysis of this study.

The economic impact on milk production of the farm of this study can be calculated by a loss of $0.30 \mathrm{~kg} / \mathrm{milk} /$ day $/$ cow in 203 cows studied, represented on average a total reduction of $1,295 \mathrm{~kg}$ of milk in the 20 days post-vaccination. As the price of milk at the time of this study was 1.60 Brazilian reais, such a decrease implied an economic loss of R $\$ 2,072.00$ Brazilian reais during the observed period.

\section{CONCLUSIONS}

Adverse reactions of FMD vaccination occur at but is not restricted to the vaccination sites.

There are also adverse systemic reactions associated with significant losses in milk production.

Local reactions are granulomas or pyogranulomas which may influence the occurrence of systemic reactions.

Adverse reactions may occur despite good practices in vaccination.

Work presented the direct negative economic impact.

Conflict of interest statement.- There are no conflicts of interest.

\section{REFERENCES}

CNA 2017. Nota técnica no 30/2017: reações adversas à vacina contra febre aftosa. Confederação da Agricultura e Pecuária do Brasil. Available at <https://www.agricultura.rs.gov.br/upload/arquivos/201711/24091100nt-cna-reacao-vacinal.pdf> Accessed on May 19, 2019.

Constable P.D., Hinchcliff K.W., Done S.H. \& Grünberg W. 2017. Veterinary Medicine. 11th ed. Elsevier, Missouri, p.2058-2067.

De Souza V.F., Soares C.O. \& Ferreira S.F. 2009. Vacinação, a importância das boas práticas e a prevenção de doenças de interesse em bovinocultura. Comunicado Técnico 122, Embrapa Gado de Corte, Campo Grande, MS. Available at <https://www.infoteca.cnptia.embrapa.br/infoteca/bitstream/ doc/853366/1/Vacinacaoaimportanciadasboaspraticaseaprevencao.pdf> Accessed on May 5, 2019.

França Filho A.T., Alves G.G., Mesquita A.J., Chiqueto C.E., Bueno C.P. \& Oliveira A.S.C. 2006. Perdas econômicas por abscessos vacinais e/ou medicamentosos em carcaças de bovinos abatidos no estado de Goiás. Ciênc. Anim. Bras. 7(1):93-96.
George M.H., Heinrich P.E., Dexter D.R., Morgan J.B., Odde K.G., Glock R.D., Tatum J.D., Cowman G.L. \& Smith G.C. 1995. Injection-site lesions in carcasses of cattle receiving injections at branding and at weaning. J. Anim. Sci. 73(11):3235-3240. <https://dx.doi.org/10.2527/1995.73113235x> <PMid:8586578>

IFAH 2012. The costs of animal disease. Oxford Analytica, Brussels. Available at<https://healthforanimals.org/component/attachments/attachments. html?task=attachment\&id=186> Accessed on Apr. 15, 2019.

Leal P.V., Pupin R.C., Santos A.C., Faccin T.C., Surdi E., Leal C.R.B., Brumatti R.C. \& Lemos R.A.A. 2014. Estimativas de perdas econômicas causadas por reação granulomatosa local após uso de vacina oleosa contra febre aftosa em bovinos de Mato Grosso do Sul. Pesq. Vet. Bras. 34(8):738-742. <https://dx.doi.org/10.1590/S0100-736X2014000800005>

Lima D.C.P., Costa A.C., Ferreira M.D.C. \& Sobrinho J.M.F. 2014. Febre Aftosa: ocorrência de nódulo pós-vacinal segundo via de aplicação da vacina. Pesq. Agropec. Gaúcha 20(1/2):167-172.

MAPA 2007. Instrução normativa no 44 de 2 de outubro de 2007. Available at<http://www.agricultura.gov.br/assuntos/sanidade-animal-e-vegetal/ saude-animal/programas-de-saude-animal/febre-aftosa/documentosfebre-aftosa/instrucao-normativa-mapa-no-44-de-02-de-outubro-de-2007. pdf/view> Accessed on Jan. 10, 2020.

MAPA 2018a. Evolução das zonas livres de febre aftosa no Brasil. Ministério da Agricultura, Pecuária e Abastecimento. Available at <http://www. agricultura.gov.br/assuntos/sanidade-animal-e-vegetal/saude-animal/ programas-de-saude-animal/febre-aftosa/documentos-febre-aftosa/ EvoluodaszonaslivresdeFA_2018.pdf> Accessed on May 19, 2019.

MAPA 2018b. Instrução Normativa no11/2018. Available at <http://www. lex.com.br/legis_27603943_INSTRUCAO_NORMATIVA_N_11_DE_18_ JANEIRO_DE_2018.aspx>. Accessed on Jan. 10, 2020.

Martinod S. 1995. Risk assessment related to veterinary biologicals: sideeffects in target animals. Rev. Sci. Tech. 14(4):979-989. <https://dx.doi. org/10.20506/rst.14.4.886><PMid:8639966>

Moro E., Junqueira J.O.B. \& Umehara O. 2001. Levantamento da incidência de reações vacinais e/ou medicamentosas em carcaças de bovinos na desossa em frigoríficos no Brasil. Hora Vet. 21(123):55-57.

Santos A.L.M., Sacramento J.P., Leão A.E., Fonseca A.P., Campos M.M., Machado F.S., Pereira L.G.R. \& Tomich T.R. 2019. Efeitos da vacinação contra febre aftosa sobre o comportamento e produção de vacas leiteiras. Embrapa Gado de Leite-Artigo em anais de congresso. Workshop de Iniciação Científica, Embrapa Gado de Leite, Juiz de Fora, MG. 4p.

Tizard I.R. 2002. Imunologia Veterinária: uma introdução. 6⿳亠丷a ed. Roca, São Paulo. 532p.

Yeruham I., Yadin H., Haymovich M. \& Perl S. 2001. Adverse reactions to FMD vaccine. Vet. Dermatol. 12(4):197-201. <https://dx.doi. org/10.1046/j.0959-4493.2001.00221.x><PMid:11493403> 